\title{
Religious and cultural space of Chasovennye Old Believers in illustrations to their new-printed books
}

\author{
Aleksandr V. Kostrov, Yulia V. Elokhina \\ Irkutsk State University, Russian Federation
}

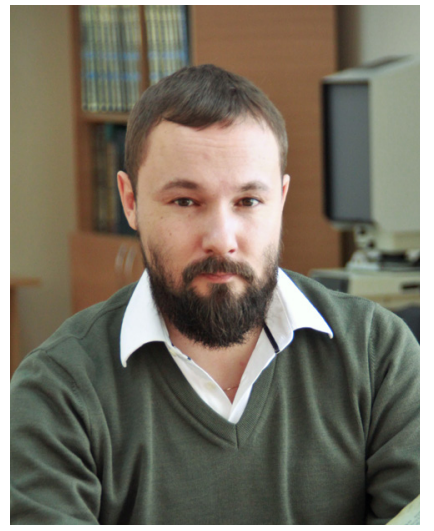

Literacy is a basic element of Old Belief culture. Alongside with early printed books being retained and reproduced, script books and manuscripts have always been an integral part of the movement. To a large extent, the tradition was maintained by the Chasovennye ("chapel goers", a non-priestly faction among Old Believers), who strictly adhered to the rule of never publishing their literature in "external" printing houses. In Yenisei Siberia, where they owned no printing housess, skete scriptoria were used as workshops for manuscripts to be hand-copied, illustrated and bound, thus producing handmade books. However, the ongoing process of creating the literature they required and the growing social demand for it provided the impetus for the developing soglasie (accord) to reconsider a number of doctrinal attitudes and principles and to start producing their own books, first hand-written and then printed in semi-uncial script (poluustav), in printing houses located in cities. These new-printed books were the phenomenon of the contemporary culture of the Chasovennye Old Believers in Krasnoyarsk region, Tuva and other regions of the country and in the world.

Along with the textual content of the books, of great interest is the tradition of illustrating them, inseparably linking the tradition of in designing Old Believers' printed books and manuscripts, to the innovative approach manifested in the apparent influence imposed by Russian and foreign (predominantly American) art with which contemporary skete indigenes are well acquainted. The evident traces of such influence are indicative of the general character of the group's contemporary culture evolving.

Of particular interest are the ways of portraying characters, objects, and loci of religious and cultural space of this relatively closed group. If considered from a comprehensive perspective, they represent visual self-reflection of their church. Their interaction with the text, on the one hand, allows implementing the doctrine, and on the other hand, manifests the logic of contemporary development of skete art. Thus it becomes possible to trace the development of both the artist's mindset and that of the addressee of the artist's works, that is members of the of Chasovennye accord

Key words: Old Belief; Chasovennye soglasie; Yenisei Siberia; new-printed books; illustration; visual anthropology; Tuva; Krasnoyarsk Krai; Khakassia; Irkutsk Oblast

\section{For citation:}

Kostrov A. V. and Elokhina Yu. V. Religious and cultural space of Chasovennye Old Believers in illustrations to their new-printed books. New Research of Tuva, 2021, no. 3, pp. 128-136. DOI: https://www.doi.org/10.25178/nit.2021.3.10

KOSTROV, Aleksandr Valeryevich, Doctor of History, Professor, Department of World History and International Relations, Irkutsk State University. Postal address: 1 Karl Marx St., 664003 Irkutsk, Russia. Tel.: +7 (914) 929-40-50. E-mail: a_kostrov@mail.ru ORCID ID: 0000-0001-5274-5424

ELOKHINA, Yulia Valerievna, Candidate of History, Associate Professor, Department of World History and International Relations, Irkutsk State University. Postal address: 1 Karl Marx St., 664003 Irkutsk, Russian Federation. Tel.: +7 (908) 641-36-57. E-mail: julflower@yandex.ru ORCID ID: 0000-0001-7639-6089

Костров Александр Валерьевич - доктор исторических наук, доцент, профессор кафедры мировой истории и международных отношений Иркутского государственного университета. Адрес: 664003, Россия, г. Иркутск, ул. К. Маркса, д. 1. Тел.: +7 (914) 929-40-50. Эл. адрес: a_kostrov@mail.ru

Елохина Юлия Валерьевна - кандидат исторических наук, доцент кафедры мировой истории и международных отношений Иркутского государственного университета. Адрес: 664003, Россия, г. Иркутск, ул. К. Маркса, д. 1. Тел.: +7 (908) $641-36-57$. Эл. адрес: julflower@yandex.ru 


\title{
Религиозно-культурное пространство часовенных старообрядцев в иллюстрациях их новопечатных книг
}

\author{
Александр В. Костров, Юлия В. Елохина \\ Иркутский государственный университет, Российская Федерация
}

\begin{abstract}
Грамотность - важный элемент старообрядческой культуры. Наряду с сохранением и воспроизведением старопечатных книг, рукописные тексты и сборники всегда были неотъемлемой частью жизни сообщества. В значительной степени эту традицию поддерживало Часовенное согласие старообрядцев-беспоповцев, которые строго придерживались правила никогда не публиковать свои книги во «внешних» типографиях, т. е. тех, которыми владела не их община. В Енисейской Сибири, где не было типографий, принадлежащих старообрядцам, скитские скриптории использовались как мастерские для копирования рукописных книг, их иллюстрирования и переплетания, - таким образом создавались новые экземпляры рукописных книг. Тем не менее, процесс создания необходимых текстов и растущий социальный спрос на такую литературу послужили стимулом того, чтобы согласие пересмотрело ряд доктринальных позиций и начало выпуск своих собственных книг, вначале написанных от руки, а затем напечатанных полууставом в городских типографиях. Эти новопечатные книги стали особым феноменом современной культуры Часовенного старообрядчества Красноярского края, Тувы и других регионов страны и мира.

Наряду с текстовым содержанием книг, большой интерес представляет традиция их иллюстрирования, неразрывно связывающая традиционное оформлению старообрядческих печатных книг и рукописей с новаторским подходом, проявляющимся в явном влиянии русского и иностранног, прежде всего американского искусства, с которым хорошо знакомы современные жители скита. Явные следы такого влияния могут многое сказать об общем характере развития современной культуры Часовенного согласия.

Особый интерес представляют способы изображения персонажей, предметов и локусов религиозного и культурного пространства этой относительно замкнутой группы. Если рассматривать их с комплексной точки зрения, они представляют собой визуальную саморефлексию старообрядческого согласия. Ваимодействуя с текстом, эти элементы, с одной стороны, позволяют не отступить от доктринальных основ, а с другой - проявляет логику современного развития скитского искусства. Таким образом, становится возможным проследить развитие мировоззрения как художника, так и адресатов его произведений художника, которым здесь предполагается стать старообрядиев Часовенного согласия.
\end{abstract}

Ключевые слова: старообрядчество; Часовенное согласие; Енисейская Сибирь; новопечатные книги; иллюстрация; визуальная антропология; Тува; Красноярский край; Хакасия; Иркутская область

Для цитирования:
Kostrov A. V. and Elohina Yu. V. Religious and cultural space of Chasovennye Old Believers in illustrations to
their new-printed books // Новые исследования Тувы. 2021, № 3. C. 128-136. DOI: https://www.doi.org/10.25178/
nit.2021.3.10

\section{Introduction}

Literacy and book culture remain the basic elements of Old Belief culture, which makes analyzing it more significant both from the point of social archaeography and that of cultural (and visual) anthropology. Traditionalism of the followers of Old Belief in this case has always had an impact on their attitude to the book - its contents, look and usage. More open denominations of Old Believers (Belokrinitskye, Novozybkovskye, Pomorskye) has recently demonstrated a more neutral attitude to the way a book looks, be it a service book (to a lesser extent) or an apocryphal book (to a larger extent), while the attitude to the book's contents remains most serious. As for the Chasovennye denomination, well-known for their high level of traditionalism in the doctrines and rituals, introducing innovations in their literature and book design may be described as a rather complicated process.

There is an ample amount of research conducted with regard to Chasovennye's literacy and book culture, among which of highest interest are those by the authors belonging to the Novosibirsk archaeographical school - N. N. Pokrovsky and N. D. Zolnikova (Pokrovsky, Zolnikova, 2002), O. D. Zhuravel (Zhuravel, 2012), N. S. Guryanova (Guryanova, 2017) and others. These and other researchers largely focus on the content of book heritage of Old Believers from Chasovennye and other accords, while we in the current work focus on the 
fact of contemporary Chasovennye publishing their books in "external" printing houses (i.e. not owned by the community of Old Believers) and on the character of their book design art development (Kostrov, 2019, 2021).

In the course of expeditions in different areas of Yenisei Siberia (2016-2021, managers A. A. Storozhenko, E. V. Bykova, A. V. Kostrov; in addition to private research trips, the 2016-2019 expeditions were under grant support $\left.^{1}\right)$, research was conducted of home, temple and skete libraries. The objectives of research were not to describe their content (including hundreds of liturgical and other books) in the minute detail; rather, the emphasis was laid on the character of religious and cultural space of Old Believers of Chasovennye denomination being reflected in the creative work of monastery artists illustrating new-printed books.

\section{Phenomenology of the Chasovennye group's new-printed books}

The phenomenon of the new-printed books is that Chasovennye - by using church books published in Old Believers' printing houses before the Schism and revolution, i. e. early-printed books and reproduced ones, - avoided producing books with application of contemporary printing technologies. Due to these and other factors, they preserved the traditional culture of hand-copying the required text (which facilitated the development of the tradition of illustrating books). However, the modernization of culture and outlook resulted in rejecting restrictions on publishing books and there appeared new apocryphal ones (kept and read beyond church) published in "external" printing houses. 10 such books ${ }^{2}$, which were published by two Krasnoyarsk printing houses, are known to exist ( 7 of which are available in the author's library, the rest are copied). These books contain not only textual, but also visual expression of the outlook typical for the Chasovennye Old Believers. They can be found in Yenisei Siberia (Krasnoyarsk krai, Tuva Republic, Khakassia, and Irkutsk oblast), and also in other enclaves of the Chasovennye denomination.

Design of new-printed books is of considerable interest from the perspective of contemporary design art typical for this complex hierarchy of Old Believers (the "sobornye", "mirskie", the groups from the Urals, western Siberia, the Far East, Yenisei, Russian and American - southern and northern, etc.) with one centre (Dubchesskye communities in the mid-Yenisei area), and also from the perspective of studying the evolving visualization of their outlook changing under the growing pressure of outside culture or cultures.

Publications vary in volume (51-700 pages), in number and quality of illustrations. Ranging from 2 to 200 , the number of illustrations does not depend on the book volume alone, for example, 64-paged and 380-paged books may contain only 2 illustrations. The principal reason lies in the controversies which may be observed in contemporary Chasovennye's new-printed books. After the illustrations galore in their first publications (issued in 2016-2017), the number of visual materials gradually declined, keeping in the latest books (issued in 2020) to a minimum.

The character of illustrations also varied, evolving from widest pluralism to strictest religious monism. Pluralism manifests itself through artists' using a variety of image sources, such as classic illustrations from church books, amateur painting or print, illustrations from western Christian literature, modern graphics and art, photographic materials (including those obtained from the Internet). The latter fact is remarkable due to the cautious stance the Chasovennye held towards photography, and also to the prohibition against using electronic communication ("the snare of the devil"). The pluralism found its manifestation in the eclectic style in the visual component of the first new-printed books. Monism of the later issues is manifested through

${ }^{1}$ Grants: RHSF No.17-14-17601 e(p) “Traditional Culture of the Old Believers of Tuva: History and Modern Times”, RFBR No. 18-09-00723A "The Yenisei Meridian" of Old Believers: Preservation and Development of the Tradition in the Conditions of Taiga Sketes and Villages", President's Grants Foundation No.18-1-013055 "Irkutsk Region Old Believers: the Role in the Cultural Development of the Region”, the grant of the Irkutsk Region Government "Old Believers of the Baikal Region as a Keeper of Traditional Russian Culture".

${ }^{2}$ Zhitie i stradanie sviatago velikomuchenika Evstafiia Plakidy [Hagiology of Saint Eustace Placidus the Martyr]. Krasnoyarsk, RASTR, 2018. 98 p. (In Russ.); O Tsarstvii Nebesnom i o vechnykh mukakh [On the Kingdom of Heaven and the eternal punishment. Krasnoyarsk, Bukva Stateinova, 2018. 328 p. (In Russ.); O khristianskikh simvolakh [On Christian symbols]. Krasnoyarsk, Bukva Stateinova, 2018. 264 p. (In Russ.); Posledniaia sed'mitsa [The Last Week]. Krasnoyarsk, Bukva Stateinova, 2020. 96 p. (In Russ); Rukopisi ottsa Simeona [Father Simeon's manuscripts]. Krasnoyarsk, RASTR, 2018. 51 p. (In Russ.); Stikh o poslednikh dniakh [A Poem of the Last Days]. Krasnoyarsk, Bukva Stateinova, 2018. 64 p. (In Russ.); Stikhi Dukhovnye [Spiritual poems]. Krasnoyarsk, Bukva Stateinova, 2019. 288 p. (In Russ.); Khristianskie mucheniki [Christian martyrs]. Krasnoyarsk, Bukva Stateinova, 2020. 524 p. (In Russ.); Chudesa Presviatyia Bogoroditsy [The Miracles of the Most Holy Virgin]. Konvoliut, s. n., 2016. 747 p. (In Russ.); Chudesa Bogoroditsy [The Miracles of the Mother of God]. Krasnoyarsk, Bukva Stateinova, 2019. 380 p. (In Russ.). 
the book being designed in one style throughout, and photographs of icons being included (only two for the whole book), which may be reckoned unique and innovative, because photographing religious items is traditionally forbidden.

Thus, the appearance of new-printed books, which are a new phenomenon for this group of Old Believers, served as an incentive to search for the proper style of illustrating them. The issue had to be discussed inclusively, thus resulting in reconsideration of attitudes towards previously existing admittances and prohibitions. From the point of bibliographical dimension of culture, the approaches to visually expressing the world outlook might be considered a mirror reflecting both traditionalism and innovations born out of the changes impelled by modern life.

\section{The sacred in illustrations of new-printed books}

Religious and cultural space mirrored in the illustrations of new books printed by Chasovennye Old Believers comprises images of God and Heaven, characters and plots of the Sacred history, as well as the loci and situations pertaining to the sacred.

Representations of God, the Mother of God, celestial hierarchy, saints and heaven appear, as a rule, in the style of traditional illustration of Old Believer books, with influence of other art schools being noticeable. Thus, "The Miracles of the Most Holy Virgin"1 (printed in 2016) book design reflects the influence of American tradition of illustrating Christian literature. This can be accounted for by the fact that not only Russian monks, but also expatriates from American communities of this accord work in monastery scriptoria (special workshops where old books are restored and new books are written and illustrated). It is here, these expatriates apply the artistic skills they obtained in different countries of Southern and North America (Brazil, Argentina, Uruguay, Bolivia, USA and Canada). This is one of the reasons for illustrative pluralism, especially in the first new-printed issues, which are distinguished by the variety in style and quality of illustrating and include a large number of photographs of nature which may be described as typically southern. Whereas in contrast, in the book "On the Kingdom of Heaven and the eternal punishment" 2 printed in 2018, the sacred images are represented by means of pictures painted in the style of old hand-copied books made by Old Believers. Therefore, it appears that the books were made by a Russian artist whose creative work had remained intact from any noticeable influence of either western religious or secular art.

The book "The Miracles of the Mother of God" ${ }^{3}$ published in 2019 is illustrated, though scarcely, with photographs of icons painted in modern workshops in the Dubchessky monasteries. It means that the illustrator seeking to follow strict canonic rules in creating religious books was given permission by thesobor (the institution for discussing and making decisions collectively, including those pertaining to matters of canon law) to use photographs of icons. In fact, it may be considered a revolution in admitted attitudes to the sacred images on the icon. The revolution became possible when the numbers of more liberal-minded monks who came to monasteries from different places helped start relative liberalization of this group of Old Believers.

Characters and plots of the Sacredhistory (the one of Christian, pre-schism Old-Orthodox and Old Believer in its Chasovennye version) are painted with appeal for tradition, while the influence of Western art remains observable. Thus, the book "Hagiology of Saint Eustace Placidus the Martyr"4 published in 2018 contains 35 watercolour illustrations made by one relatively professional artist. There, St Eustace and his surroundings are represented as earthly people enduring life ordeals. The representations cannot be considered authentically Old Believer since they are similar to those in books issued by other Christian confessions. However, everything changes when it pertains to the cultural characters continuing the Sacred history in the framework of the Chasovennye group Church. The characters in question are monks and nuns of remote and out-of-the-way monasteries located in Siberian taiga (Bykova, Prigarin, 2019). These monks and nuns are thought to be living in the "world-renouncing", "pure" and sacred space of the last communities of true believers. Here it is possible to see the recognizable images of black clergy monks and nuns (the name given by Chasovennye to

\footnotetext{
${ }^{1}$ Chudesa Presviatyia Bogoroditsy [The Miracles of the Most Holy Virgin]. Konvoliut, s. n., 2016. 747 p. (In Russ.).

${ }^{2} \mathrm{O}$ Tsarstvii Nebesnom i o vechnykh mukakh [On the Kingdom of Heaven and the eternal punishment]. Krasnoyarsk, Bukva Stateinova, 2018. 328 p. (In Russ.).

${ }^{3}$ Chudesa Bogoroditsy [The Miracles of the Mother of God]. Krasnoyarsk, Bukva Stateinova, 2019. 380 p. (In Russ.).

${ }^{4}$ Zhitie i stradanie sviatago velikomuchenika Evstafiia Plakidy [Hagiology of Saint Eustace Placidus the Martyr]. Krasnoyarsk, RASTR, 2018. 98 p. (In Russ.).
} 
mantle or schema monks among others) created realistically enough to be recognized and conventionalized to fit into the traditional style of Old Believer book illustration. Naturally, the characters remain within the context of personal holiness and the Sacred history. For example, in the above-mentioned book "On the Kingdom of Heaven and the eternal punishment" 1 on page 118 a monk with a halo over his head is portrayed picking fruit from a tree under the sun. The symbols clearly imply monastery holiness (halo), God (the Sun) and heavens (the fruitful tree). Page 5 of the book, preceding the chapter "On Heaven", contains an image of the Mother of God who is holding flowers while standing near the heavenly tree under the sun and meeting the host of nuns with lestovkas (Old Believers' prayer ropes with profoundly symbolic meaning) in their hands and walking toward her. A pigeon (the symbol of the Holy Spirit) is sitting on the heavenly tree, and halos are painted over all the nuns' heads.

It is not common that monastery artists portray monks as saints. It becomes clear that only those who are the best, who are in the Kingdom of Heaven, may be portrayed as such. In the earthly context, black clergy are painted without a halo. It can partly be accounted for as follows: having renounced priesthood, Chasovennye found themselves in a controversial situation with respect to canonizing their prominent religious

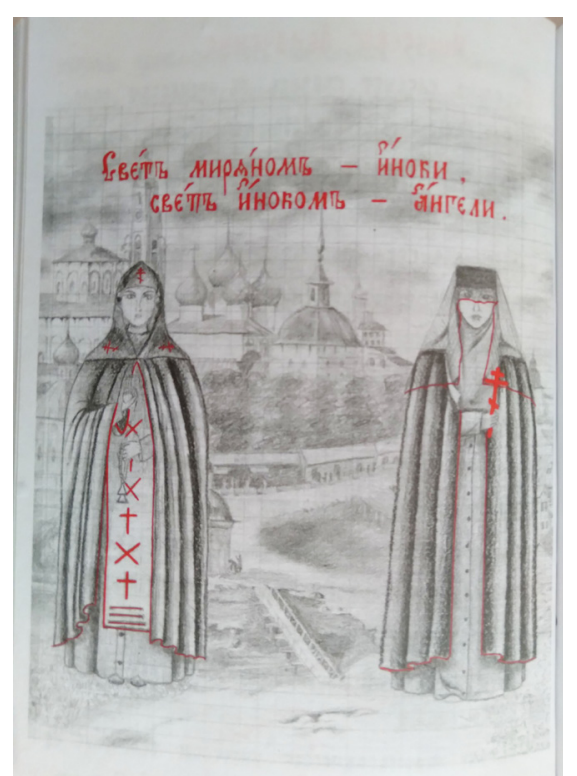

Illustration №2 Two nuns in the background of an old monastery. The illustration of the book "About Christian symbols". Photo by the author.

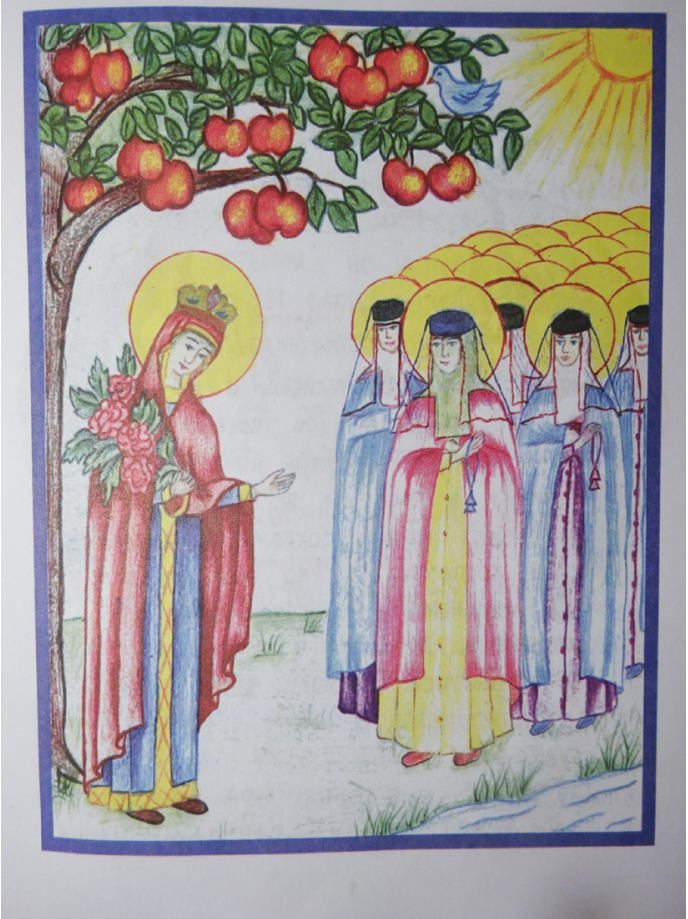

Illustration № 1 The image of the Mother of God meeting the holy nuns.

leaders. However, an The illustration of the book "About the Kingdom of Heaven earthly monk was to be seen as an exemplar.

Thus, in the book "On Christian symbols" 2 published in 2017, page 224 , figures of two nuns (one of which is holding a lestovka) in the background of an old monastery are supplied with a commentary "Monks are beacons for laymen, angels are beacons for monks".

The highest number of images showing Chasovennye skete residents can be found in the book "The Miracles of the Mother of God" ${ }^{3}$ (2016). In some of the images they are represented beyond the visible connection with Heaven (giving the text a complete control over it), - for example, on page 196 where the illustration shows a monk thoughtfully contemplating the fire engulfing his cell. Still, the overwhelming majority of the visual images portraying monks contain the sign of their visible connection with Heaven. Page 349 in the book "The Miracles of the Mother of God"4, for instance, presents a monk praying with God's Mother's lestovka while standing near a tree. His prayers are turning into flowers being collected by the Mother of God standing behind his left shoulder. On pages 59, 81-82, 480 and 557 of the book the monks' vision of the Mother of God can be seen. It is of importance that the monks' clothes look very similar to the clothes worn by Chasovennye's monks in monasteries.

${ }^{1}$ O Tsarstvii Nebesnom i o vechnykh mukakh [On the Kingdom of Heaven and the eternal punishment]. Krasnoyarsk, Bukva Stateinova, 2018. 328 p. (In Russ.).

${ }^{2}$ O khristianskikh simvolakh [On Christian symbols]. Krasnoyarsk, Bukva, 2018. Stateinova. 264 p. (In Russ.).

${ }^{3}$ Chudesa Presviatyia Bogoroditsy [The Miracles of the Most Holy Virgin]. Konvoliut, s. n., 2016. 747 p. (In Russ.).

${ }^{4}$ Ibid. 


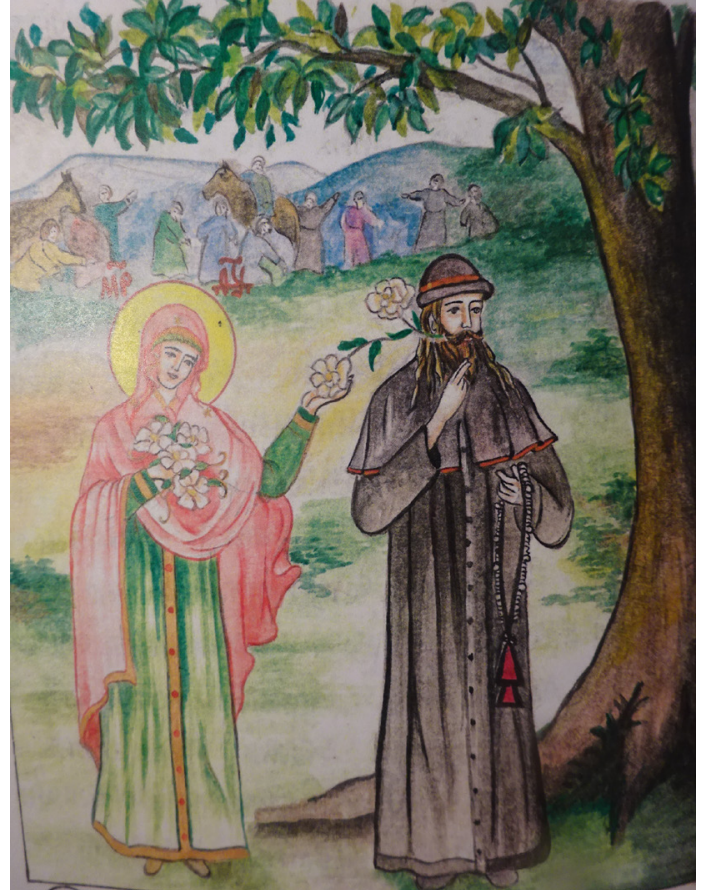

Illustration № 3 A monk praying with the Mother of God's lestovka (Old Believers' prayer ropes). The illustration of the book "The Miracles of the Most Holy Virgin". Photo by the author.

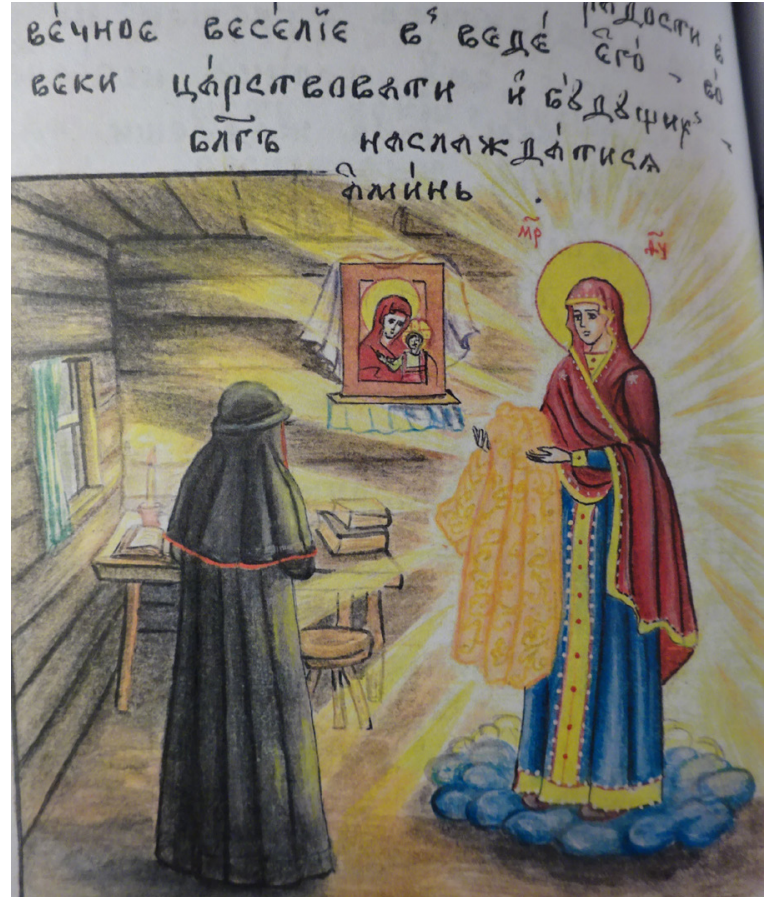

Illustration № 4 Monks'vision of the Mother of God in the cell. The illustration of the book

"The Miracles of the Most Holy Virgin”. Photo by the author.

Besides the monk being seen as a cultural example, a truly believing layman is also represented as one, with the artist (particularly in the amply illustrated book “The Miracles of the Mother of God”) portraying a layman wearing antique clothing in Byzantine or old Russian style. A number of paintings include elements of classic old Russian Orthodox garments (a skewed-collared shirt with a belt, a pinafore dress, a pinned headscarf) used by Old Believers as everyday, festive and, especially, praying clothes. Thus a historical true believer's image correlates to the image of a contemporary Christian, here, a follower of the Chasovennye accord of Old Believers.

Visual representations of the church are another manifestation of the sacred space. No single illustration depicts the outer structure of a village or skete church. Instead, all of them refer to old orthodox churches and monasteries, including those built in the baroque style. In the book "The Miracles of the Mother of God", page 36, the Church in Heaven is represented as a group of monasteries located on the clouds. In the book "Hagiology of Saint Eustace Placidus the Martyr"1, the temple dedicated to the title character is depicted as Church of the Intercession on the Nerl (page 80). In the book "On the Kingdom of Heaven and the eternal punishment" 2 the church image is used three times. While in the first case it is a graphic image of several temple constructions (p. 157), in the second and third there are photographs presenting old wooden churches (pp. 96, 110). In the book "On Christian symbols" 3 besides the picture showing an old Russian wooden church, there are a painting of another built in the post-Schism style (p. 201) and a photograph of a pre-schism stone church (p. 125) with the photograph "The Kyiv Pechersk Lavra - the first monastery in Russia. Founded in 11 th century" (p. 258-259). Thereby a reference is made to the place where the monastic tradition, which is developed contemporarily in the Dubches-river area (the tributary of the Yenisei, where Chasovennye's monasteries are located), came to Russia. Of particular interest is that the artist was not confused by either using photographs (as was mentioned above, photographing the sacred sphere is strictly forbidden in the

\footnotetext{
${ }^{1}$ Zhitie i stradanie sviatago velikomuchenika Evstafiia Plakidy [Hagiology of Saint Eustace Placidus the Martyr]. Krasnoyarsk, RASTR, 2018. 98 p. (In Russ.).

${ }^{2} \mathrm{O}$ Tsarstvii Nebesnom i o vechnykh mukakh [On the Kingdom of Heaven and the eternal punishment]. Krasnoyarsk, Bukva Stateinova, 2018. 328 p. (In Russ.).

${ }^{3}$ O khristianskikh simvolakh [On Christian symbols]. Krasnoyarsk, Bukva Stateinova, 2018. 264 p. (In Russ.).
} 


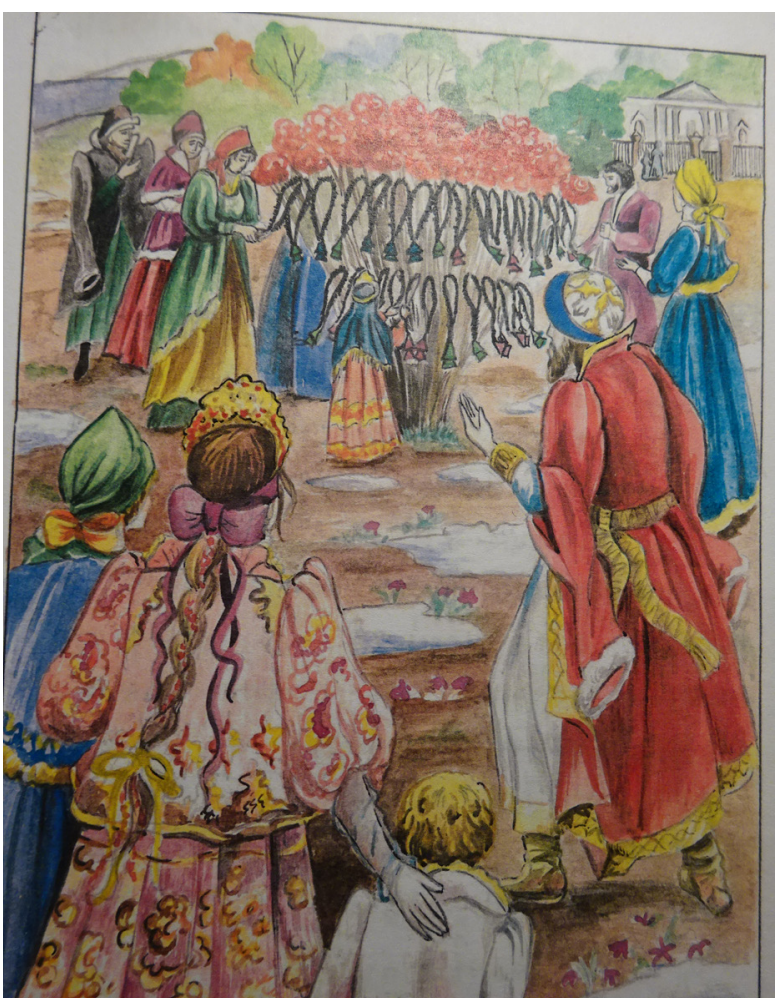

Illustration № 5. The tree with lestovka (Old Believers' prayer ropes) growing from it. The illustration of the book "The Miracles of the Most Holy Virgin". Photo by the author.

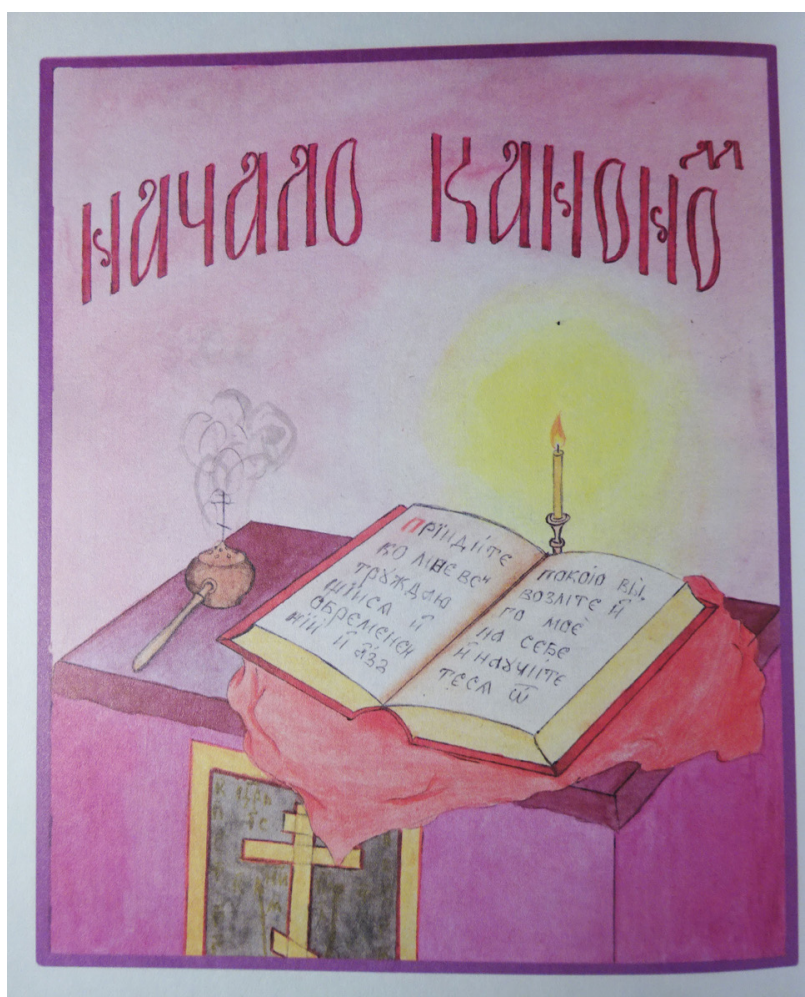

Illustration № 6. Old Believers' icon stand with a church book, a candle and a hand-censer. The illustration of the book "Hagiology of Saint Eustace Placidus the Martyr". Photo by the author.

Chasovennye accord) or by presenting the contemporary view of the monastery that was cardinally rebuilt in the post-Schism time allowing innovations in architecture. Moreover, the processed photograph printed at the end of the brochure "A Poem of the Last Days" presents the image of a pregnant woman praying before the altar-screen in a large stone church. Obviously, this photograph was taken in one of the new churches and has nothing to do with the Chasovennye tradition, as is suggested by the interior of the monastery, garments, etc. This example makes it possible to state that in order to visualize particular passages in the text, photographs of newly built temples, rather than those of Old Believers' ones, can be used.

Special emphasis should be laid on the manner of depicting such an important marker of Old Belief culture as the lestovka (or "lestvitsa", i. e., the ladder showing ascension by praying). Being the Old Orthodox prayer ropes with profoundly symbolic meaning, lestovka varies in the way it is perceived and used by various Old Believer groups and denominations. For example, Chasovennye use not only "Isusova" (Jesus's) but also "Bogorodichnaya" (the Mother of God's) lestovkas and other types (various forms of special lestovkas "for travel" and the combined Jesus's and the Mother of God's). While the podrushnik (a special carpet for praying and bowing to the ground) can be found merely a few times in the illustrations to new-printed books, the lestovka appears there quite frequently. For instance, in the book "On Christian symbols" it is shown only 4 times, whereas in "The Miracles of Mother of God" ${ }^{3}$, as many as 31 times; it is also mentioned in many apocryphal stories published in this issue and is at the heart of the plot of a number of them (e. g. "O dreve na nem zhe lestvitsy izrastosha" (On the tree whereupon ladders grew) and others). This testifies to the lestovka's significance for religious practice and the cultivated image of salvation.

Regarding the loci related to the sacred and reflected in the illustrations, besides the nature, street or chambers where a Christian can have a vision of miracles, there are khoromina (living quarters), a cell and a

${ }^{1}$ Stikh o poslednikh dniakh [A Poem of the Last Days]. Krasnoyarsk, Bukva Stateinova, 2018. 64 p. (In Russ.).

${ }^{2}$ O khristianskikh simvolakh [On Christian symbols]. Krasnoyarsk, Bukva Stateinova, 2018. 264 p. (In Russ.).

${ }^{3}$ Chudesa Presviatyia Bogoroditsy [The Miracles of the Most Holy Virgin]. Konvoliut, s. n., 2016. 747 p. (In Russ.). 
temple, with all of them portrayed symbolically and stylized in consonance with the task to visualize Christian history. Therefore, particulars of arranging the sacred space in Chasovennye's domestic and church life are fragmented and rarely seen. The process occurs through incorporating the contemporary images known to the artist into the context of the visualized plot of Christian history of the bygone times, and other areas, and also through confirming the righteousness and salutariness of the chosen religious way of life. Illustrations show views of the icon corner, the icon stand (with a hanging icon-stand cover), one or three lighting candles on it (for praying by the book, because using electric lighting for this purpose is forbidden), a hand-censer (which is widely used among Old Believers) and others.

These elements help manifest not only the distinguishing features of Chasovennye Old Believers' religious lifestyle, but also the system of prohibitions common among them. The former can be observed in the costumes worn by monks and laymen, the lestovka and podrushnik, the hand-censer, the structure of the icon corner and icon stand, etc. The latter becomes evident in praying without using electricity (with one or three lighting candles), in forbidding to photograph their sacred sphere and to use the photographs of the outer sphere for illustrations, and also in stylizing drawings which allows to avoid realistic representation.

However strict the community may be, its artist is allowed a certain extent of artistic liberty. For example, despite the relatively strict rules of church lifestyle, of creating and using images of it, a contemporary Chasovennye illustrator may occasionally depart from a rule. In doing so, he uses graphic and photographic images of churches different from the Old Belief tradition, occasionally depicts the cross on their domes asa mirror image, presents women standing on men's (right) side of the church during a service, etc. This may stem from his neophyte origin and relatively low church-service awareness. Nevertheless, the fact that these paintings were allowed by the monastery council to be published suggests that liberalization of attitudes and practices is becoming possible.

\section{Conclusion}

Thus, it took illustrating new-printed books several years to evolve from the early pluralism comprising a variety of image sources to the rigorously simplified number and quality of illustrations indicative of returning to classic examples of traditional culture. Judging from informants' comment and the style used in designing later books, experimental diversity in book design was condemned by the orthodoxically thinking part of the skete community, which, in the framework of replacing visual blocs of the outer culture in the publications, sanctioned the use of photographs of their icons. Taking the existing prohibitions into consideration, this may be regarded as a phenomenon worthy of attention and allows us to speak of the evolutionary character of tradition.

\section{REFERENCES}

Bykova, E. V. and Prigarin, A. A. (2019) Vizual'nyi obraz chernoriztsa v starovercheskikh rukopisiakh na Enisee [Visual image of a monk in Old Believer manuscripts on the Yenisei]. In: Materialy Mezhdunarodnykh XVIII etnograficheskikh chtenii «Etnos $i$ konfessiia» [Proceedings of the International XVIII Ethnographic Readings "Ethnos and Confessions"]. Ed. by V. M. Grusman and E. E. Gerasimenko. St. Petersburg, IPC SPbGUND. 260 p. Pp. 33-38. (In Russ.).

Gur'ianova, N. S. (2017) Rukopisnye sborniki i oformlenie ideologii staroobriadcheskogo dvizheniia [Handwritten collections and design of the ideology of the Old Believer movement]. Novosibirsk, NIC Apostrof. 230 p. (In Russ.).

Zhuravel', O. D. (2012) Literaturnoe tvorchestvo staroobriadtsev XVIII - nachala XXI v.: temy, problemy, poetika [Literary works of the Old Believers in the 18th - early 21st centuries: themes, problems, poetics]. Novosibirsk, SO RAN Publ. 438 p. (In Russ.).

Kostrov, A. V. (2019) Novopechatnye knigi staroobriadtsev chasovennogo soglasiia: igra traditsii i novatsii [New-printed Books of Old Believers of Chasovennye Accord: A Game of Tradition and Innovation]. In: Trudy IV Mezhdunarodnoi nauchnoi konferentsii «Iazyk, kniga i traditsionnaia kul'tura pozdnego russkogo srednevekov'ia v nauke, muzeinoi i bibliotechnoi rabote» [Proceedings of the IV International Scientific Conference "Language, Book and Traditional Culture of the Late Russian Middle Ages in Science, Museum and Library Work”]. Comp. by Yu. S. Belyznkin, E. V. Vorontsova and N. V. Litvina. Moscow, MGU Publ. 783 p. Pp. 165-175. (In Russ.).

Kostrov A. V. (2021) Fenomeny kultury sovremennyh staroobradcev-chasovennyh Eniseiskoi Sibiri [Cultural Phenomena of modern Old Believers belonging to Chasovennoe soglasie of Yenisei Siberia]. Krasnoyarsk, KASS. 412 p. (In Russ.). 
Pokrovskii, N. N. and Zol'nikova, N. D. (2002) Starovery-chasovennye na vostoke Rossii v XVIII-XX vv.: Problemy tvorchestva i obshchestvennogo soznaniia [Chasovennye Old Believers in the East of Russia in the 18 ${ }^{\text {th }}-20$ th Centuries: Problems of Creativity and Social Consciousness]. Moscow, Pamiatniki istoricheskoi mysli. 471 p. (In Russ.).

Submission date: 30.04.2021.

\section{СПИСОК ЛИТЕРАТУРЫ}

Быкова Е. В., Пригарин А. А. (2019) Визуальный образ черноризца в староверческих рукописях на Енисее // Материалы Международных XVIII этнографических чтений «Этнос и конфессия» / отв. ред. В. М. Грусман, Е. Е. Герасименко. СПб. : ИПЦ СПбГУДТ. 260 с. С. 33-38.

Гурьянова Н. С. (2017) Рукописные сборники и оформление идеологии старообрядческого движения. Новосибирск : НИЦ «Апостроф». 230 с.

Журавель О. Д. (2012) Литературное творчество старообрядцев XVIII - начала XXI в.: темы, проблемы, поэтика. Новосибирск : Изд-во СО РАН. 438 с.

Костров А. В. (2019) Новопечатные книги старообрядцев часовенного согласия: игра традиции и новации // Труды IV Международной научной конференции «Язык, книга и традиционная культура позднего русского средневековья в науке, музейной и библиотечной работе» / сост. Ю. С. Белянкин, Е. В. Воронцова, Н. В. Литвина. М. : Изд-во МГУ. 783 с. С. $165-175$.

Костров А. В. (2021) Феномены культуры современных старообрядцев-часовенных Енисейской Сибири. Красноярск : КАСС. 412 с.

Покровский Н. Н., Зольникова Н. Д. (2002) Староверы-часовенные на востоке России в XVIII-XX вв.: Проблемы творчества и общественного сознания. М. : Памятники исторической мысли. 471 с.

Дата поступления: 30.04.2021 2. 